\title{
LOS ATENEOS LIBERALES: POLÍTICA, CULTURA Y SOCIABILIDAD INTELECTUAL
}

por

\author{
Francisco Villacorta Baños
}

Instituto de Historia, C.S.I.C., Madrid

RESUMEN: El ateneo liberal es la primera y la más conocida institución de las múltiples cobijadas bajo dicho nombre en la cultura españ்la contemporánea. Desde la creación del pionero Ateneo de Madrid en 1835 una extensa red provincial de entidades del mismo género aglutinará a lo largo de un siglo lo más granado de la élite política y cultural de su respectivo ámbito, intentando abarcar, en un ambicioso proyecto de libre pensamiento, el ejercicio de la enseñanza académica, el cultivo y la discusión de los resultados de la ciencia y la difusión de las primicias de la creación literaria y artística. En cuanto instituciones liberales, sobrellevaron difícilmente el largo periplo de la dictadura franquista basta alcanzar en algún caso el tiempo presente, bien es cierto que sin el preponderante papel cultural que en su momento llegaron a gozar.

Palabras Clave: Ateneo. Cultura. España. Intelectuales. Liberalismo. Siglos XIX y XX. Sociabilidad.

ABSTRACT: The liberal "ateneo» (cultural club) is the first and bets known institution of the many contained under that umbrella in modern Spanish culture. From the creation of the pioneering Ateneo de Madrid in 1835 an extensive provincial network of organisations of the same type bound together the cream of the political and cultural elite, aspiring to encompass (in an ambitious project of free thought) the exercise of academic education, the cultivation and discussion of scientific developments, and the diffusion of literary and artistic creativity. Liberal institutions of this type survived the long years of the Franco dictatorship, albeit with great difficulty, into the present time, although -it is true- without the leading cultural role they once enjoyed.

KEY wORDS: Ateneo. Culture. Spain. Intelectuals. Liberalism. Nineteenth century. Twentieth century. Sociability. 
El nombre genérico de «ateneo» encarna una de las experiencias culturales más duraderas, prestigiosas y sugerentes de la historia contemporánea de España. Recuperado en los albores del siglo XIX desde la remota historia cultural helenística y latina, su aparición enlaza directamente con el nacimiento coetáneo en toda Europa de toda una serie de instituciones (salones, clubs políticos, sociedades patrióticas, círculos masónicos, cafés literarios, centros artísticos) cuya acción constituye una característica sociológica fundamental de la difusión del liberalismo romántico en su sentido más amplio.

Son en su conjunto, pues, instituciones estrechamente vinculadas con la aparición del espacio público liberal y burgués que organiza la competencia ideológica en las nuevas tareas del gobierno político y en el reconocimiento y promoción de los nuevos gustos estéticos. En España, en todas esas tareas sobresalen con especial relevancia los ateneos, en particular los acogidos a esa significación liberal aquí analizada, aunque al prestigio de esa denominación genérica terminen también por acogerse más adelante otros grupos sociales o profesionales (ateneos mercantiles, médicos, normalistas, militares, escolares, femeninos, libres, ultramarinos...), entre ellos el obrerismo organizado, que rotulará con él algunos de sus centros de reunión y sus propias inquietudes culturales (ateneos populares, sindicalistas, socialistas y libertarios), y cuya historia el lector encontrará en otro lugar de este monográfico'.

Si tomásemos como guía el modelo consagrado por el pionero Ateneo madrileño, se trataría de un centro de cultura en una triple acepción: academia científica, instituto de enseñanza superior y círculo literario y artístico. Una propuesta de ambicioso alcance, proyectada sobre el amplio escenario del espacio público de la razón y de las sociabilidades electivas que alumbra el nuevo siglo, pero además íntimamente enraizada en la cultura enciclopédica e ilustrada de su momento inicial. Explayada a continuación con notable éxito durante décadas, si bien no en los términos estrictos a que remite aquella fórmula cultural, el paso del tiempo lo irá modelando sobre los cambios estructurales operados en la cultura, sobre su profesionalización, su progresiva institucionalización académica o sus modulaciones de tipo social, de forma que aquellas categorizaciones sociales e institucionales terminarán por diluirse relativamente ante las expectativas diversificadas de los nuevos hombres de cultura. De esta forma, serán estos que ya podemos llamar intelectuales en sus diversas acepciones, y sus estrategias de afiliación, reconocimiento y consagración, los que acabarán por hipostasiar la vida de los ateneos - de las instituciones culturales en general - y modelar sus potencialidades en el amplio espectro de las relaciones entre cultura y sociedad de todo un siglo.

Retomando el prototipo madrileño, durante un siglo pasan por él como profesores, conferenciantes, polemistas, estudiosos o simplemente oyentes, la

1 SÁNCHEZ GARCía, José Luis: La voluntad regeneracionista. Esfuerzo e inercia del Ateneo de Valladolid, 1872-1936, Palencia, Región Editores, 1998, pp. 11-12 y 17.

Hispania, LXIII/2, núm. 214 (2003) 415-442 
muestra más representativa de la intelectualidad española, en todas las acepciones que a este concepto quepa atribuirle. $Y$ en concordancia con esa pluralidad, la nómina de las inquietudes culturales acogidas a su hospitalidad presenta rasgos de una curiosidad casi universal, omnicomprensiva del variado utillaje mental de las sucesivas generaciones intelectuales amalgamadas en el crisol ateneísta; en definitiva, el universo cultural y político segregado por la dinámica histórica que ha ido diseñando la sociedad presente, lo mismo en el campo de la filosofía política y jurídica del orden liberal burgués, que en el del pensamiento científico, en la investigación erudita y en las primicias de la creación literaria y artística, sin olvidar algo que resulta particularmente visible en sus primeras etapas y que conservará más o menos en sordina a lo largo de toda su historia democrática: una peculiar implicación en las vicisitudes de la vida política.

Otro tanto se podría decir del resto de los ateneos, cada uno en su propio ámbito local, adaptados a las condiciones particulares de su medio. Hay, en la historia de los ateneos, una razón, que catalogaríamos de «ecología cultural», que no podemos obviar de entrada como aviso ante la referencia constante que nos veremos precisados a hacer del prototipo ateneísta madrileño. En buena parte de aquéllos, la particular adaptación al medio terminará por convertirse en una posición activa en torno a la cultura local y, a la larga, a su implicación en el debate regionalista o nacionalista. El prototipo más acabado a este respecto será, como veremos, el Ateneo de Barcelona. Estas son pues las perspectivas que se pretenden desarrollar someramente a continuación.

\section{OCUPAR EL ESPACIO PÚBLICO}

Las modernas investigaciones acerca de las condiciones sociales e intelectuales que enmarcan el cambio político hacia el liberalismo han puesto de relieve la importancia de la nueva «esfera pública política», caracterizada por la libertad de crítica y discusión frente al poder público constituido y por su cristalización como emblema de un nuevo estrato social «burgués», en el combate a la vez por la identidad y por el sentido de las nuevas élites sociales que protagonizarán la aventura histórica del mundo contemporáneo.

Su tiempo es el de la difusión de las luces del siglo XVIIII y del kantiano uso público de la razón, momento en el que, frente al peso de las jerarquías y de los valores dominantes, se emplaza en la economía del poder público el valor de la razón en libre disponibilidad y en abierta confrontación. Astucia de ésta es además que estas nuevas condiciones intelectuales se expandan ampliamente en un principio en los campos de las actividades económicas privadas y de la crítica literaria y del gusto artístico, que ofrecen un terreno aparentemente más neutral que el de la filosofía política, para ganar posteriormente espacio en el conjunto de la cultura letrada. Que emplacen su apuesta desde el principio en los nuevos centros de sociabilidad libre, donde los individuos se reúnen 
en plano de igualdad en virtud de su valor personal y no corporativo, donde los cargos y las decisiones responden a un principio democrático, es otra de las apuestas de alcance entre las novedades del nuevo siglo. Bien es verdad que todo ello es ya de un valor añadido —el que abanderan los nuevos públicos letrados y las nuevas élites económicas - acotado entre la esfera del despotismo ilustrado «populista» y el pueblo ajeno a los pormenores de la cultura letrada ${ }^{2}$.

Estas apreciaciones, aun generales, sirven perfectamente para enmarcar el nacimiento de las instituciones que tenemos en perspectiva. La continuidad de las tradiciones ilustradas ha sido sorprendida por Antonio Ruiz Salvador en el espíritu que informa la creación en 1820, al inicio de la coyuntura política del Trienio Constitucional, del Ateneo Español de Madrid, antecedente directo del actual Ateneo Científico, Literario y Artístico de Madrid. Fundado por «hombres de espíritu liberal, dispuestos a trabajar por la ciencia y el progreso", con la intención de difundir "la instrucción pública», condición indispensable de la «verdadera libertad» y de la "consolidación y progresos del sistema constitucional» y de la "fiel observancia de las nuevas instituciones», con el objetivo final de cooperar de este modo a «la prosperidad de la nación», aquel primer Ateneo responde arquetípicamente al carácter transacional y a la efervescencia política de la etapa heroica del liberalismo español ${ }^{3}$.

Y otro tanto se podría decir del espíritu que informa la creación en 1835 del definitivo Ateneo madrileño, sólo que ya se encajaba dentro del espíritu moderado que daba el tono político a los años treinta del siglo, el del romanticismo templado y conservador de los viejos doceañistas. Fue hijuela de otra típica institución dieciochesca, la Sociedad Económica Matritense, a la que su época debe no pocas iniciativas de alcance, pues uno de sus socios, Juan Miguel de los Ríos, tomó la iniciativa de reconstituir el Ateneo del año 20, a la vez como enlace y como ruptura con el espíritu liberal que había cristalizado en aquél ${ }^{4}$. Y, desde el principio, el Ateneo madrileño tuvo el objetivo confeso de participar en la «difu-

2. Es obligada la referencia al trabajo central de HABERMAS, Jürgen: Historia y crítica de la opinión pública. La transformación estructural de la vida pública, México, Ediciones $G$. Gili, última reimpresión, 2002. Ver además CHARTIER, Roger: Espacio público, crítica y desacralización en el siglo XVIII. Los orígenes culturales de la Revolución francesa, Barcelona, Gedisa, 1995.

3 Ruiz Salvador, Antonio: El Ateneo Científico, Literario y Artístico de Madrid (1835-1885), London, Tamesis Books, 1971, pp. 15-32. Ver también GIL NovALES, Alberto: El primer Ateneo (1820-1823), Madrid, Ateneo de Madrid, 1986; MALLO, T.: «Ciencia e instrucción en el Ateneo Español de Madrid (1820-1823)", en Díez Torre, A. R., Mallo, T. y Pacheco Fernández, D. (Eds.): De la Ciencia Ilustrada a la Ciencia Romántica, Madrid, Ateneo de Madrid-Doce Calles, 1995, pp. 567-573; y, sobre su marco general, ARTILES, G.: «De la época romántica. Larra y el Ateneo», Revista de la Biblioteca, Archivo y Museo, Madrid, t. 8, 1931, pp. 137-151.

4 Remitimos para estas primeras etapas del Ateneo de Madrid a su bibliografía fundamental: LABRA, Rafael $\mathrm{M}^{2}$ de: El Ateneo de Madrid. Sus orígenes, desenvolvimiento, representación y porvenir, Madrid, 1878, p. 12. En 1906, saldría su segunda aportación bibliográfica sobre él: El Ateneo de Madrid (1835-1905). Notas bistóricas, publicado en Madrid. Ver además, por supuesto, el libro ya mencionado de Ruiz Salvador, Antonio. 
sión de las luces» y en la «educación moral» de los ciudadanos y de contribuir al debate político y atender a la formación de la opinión pública; aspectos todos que fundamentan y consolidan la libertad del nuevo siglo y sus instituciones políticas representativas. Unos objetivos programáticos para una institución cultural libremente organizada, conforme al modelo asociativo de los clubes ingleses, fuera de la asfixiante atmósfera de la protección cultural regia del pasado siglo5.

\section{UN MODELO PIONERO DE ORGANIZACIÓN CULTURAL: EL ATENEO DE MADRID}

Desde su origen, el Ateneo de Madrid de 1835 ha sido considerado indistintamente como Academia Científica, Instituto de enseñanza y Círculo literario, integrando, pues, los componentes todos de una acción cultural ilustrada y enciclopédica, que era la fórmula conceptual de la cultura de su etapa originaria.

En la primera acepción, sus actividades se realizaban en las Secciones de Ciencias Morales y Políticas, Ciencias Naturales, Ciencias Matemáticas y Literatura y Bellas Artes. En ellas, se leían y debatían los más diversos temas de actualidad científica, cultural y literaria del momento, según el modelo de las Academias de científicos aficionados surgidas en el Renacimiento italiano y asumidas más adelante por las monarquías ilustradas europeas, añadiéndoles su patrocinio y su apoyo oficial en la empresa de transformación ilustrada de la sociedad. Instituciones como la Royal Society inglesa o la Academia de las Ciencias francesa fueron durante los siglos XVII y XVIII la avanzadilla del movimiento cientifista, pero a la larga sus realizaciones contribuyeron también de forma decisiva a la institucionalización de la ciencia en los términos modernos de un método científico y de una práctica académica alejados de las amplias y ambiguas especulaciones científico-naturalistas de aquel movimiento.

Pero además, las Secciones eran metodológicamente centros de discusión, de análisis, de intercambio intelectual, con profundos cimientos en la fe racionalista del siglo XVIII: la existencia de una Razón universal impresa en la mente de cada individuo, que debía aflorar allí donde varios espíritus individuales explayaban sus opiniones en abierta confrontación intelectual. La oratoria, el gran medium de la razón política durante estas primeras etapas de los organismos representativos, tuvo en estas instituciones su templo de aprendizaje y de ensayo general, que proporcionó a la ambición juvenil las primeras bazas políticas y un instrumento de primer orden para toda la carrera pública.

"Antesala del Parlamento", según lo catalogó Unamuno', emblema de una democracia organizacional, donde vérselas con una masa "que vota», en pala-

5 Resumen del discurso del primer presidente, el duque de Rivas, en LABRA, Rafael $M^{\text {a }}$ de: $E l$ Ateneo de Madrid. Sus orígenes, op. cit., pp. 69-72.

6 UnAmuno, Miguel de: «La evolución del Ateneo de Madrid», artículo publicado en $\mathrm{La} \mathrm{Na}$ ción el 24 de enero de 1916, y recogido en sus Obras Completas, t. VIII [Autobiografía y recuerdos personales], Madrid, Escélicer, 1966, p. 367. 
bras de Manuel Azaña («este ejercicio de polemista y el hábito de entendérmelas con una muchedumbre (que vota) es lo que yo he sacado del Ateneo y que me sirve en la política) ${ }^{7}$; el Ateneo madrileño bien representó el aprendizaje y el ritual democrático, por consiguiente, hasta etapas bien avanzadas del parlamentarismo del siglo XX y hasta la deformación de lo que se podría llamar el «intelectualismo ateneísta», que el siempre agudo Josep Pla definía como una forma de abordar las cuestiones exclusivamente a través de su enfoque teórico, lo que significaba en la práctica acotar certeramente los problemas, definir sus soluciones, discutirlas, votarlas y, a partir de ahí, dar los problemas por resueltos, sin atender la posterior prueba de la realidad ${ }^{8}$.

En cuanto Instituto de enseñanza, el Ateneo proveía cátedras públicas y gratuitas. Durante mucho tiempo, los más destacados hombres de cultura explicaron allí, a la sombra de la libertad, disciplinas que todavía pugnaban por encontrar su sitio en la vida académica oficial. Labra lo compara en esta tarea docente con el Colegio de Francia, aunque atribuyendo a éste, frente al Ateneo, la particularidad de estar financiado, intervenido y organizado por el Estado?. No es posible desvincular esta crucial tarea en las etapas iniciales del liberalismo del papel histórico de las Universidades clásicas en su lenta y trabajosa adaptación organizativa a los mecanismos de control y tutela de los nuevos sistemas educativos estatales y en su apertura hacia las disciplinas laicas modernas ${ }^{10}$. En esa perspectiva, apenas será bastante todo lo que se pondere acerca de la importancia del Ateneo de Madrid, relativamente solitario primero, en concomitancia con otras instituciones y ámbitos intelectuales después, en la penetración del pensamiento europeo contemporáneo, en el debate inicial de las novísimas teorías filosóficas y científicas nacionales e internacionales - administración, derecho político constitucional, economía política, crédito público, derecho internacio-

7 AZAÑA, Manuel: «Memorias políticas y de guerra», en Obras Completas, t. IV, México, Oasis, 1968, p. 396. Sobre el papel del Ateneo de Madrid en la biografía intelectual y política de Azaña, ver Villacorta BAÑos, Francisco: "Azaña y el Ateneo de Madrid. Una memoria olvidada», en Serrano, V. A. y San Luciano, J. M.: Azaña, Alcalá de Henares, Fundación Colegio del Rey, $2^{\text {a }}$ edición, 1991, pp. 407-437, y «Manuel Azaña et l'Ateneo de Madrid (1913-1921), en AMALRIC, Jean-Pierre y AUBert, Paul (Eds.): Azaña et son temps, Madrid, Casa de Velázquez, 1993, pp. 47-65.

8 PLA, Josep: De la Monarquía a la República, Barcelona, Acervo, 1977, p. 54.

9 LABRA, Rafael $\mathrm{M}^{\mathrm{a}}$ de: El Ateneo de Madrid. Sus orígenes, op. cit., pp. 9-10.

$10 \mathrm{Al}$ respecto sigue siendo básico, aunque desde luego monografías parciales sobre Universidades concretas (Universidad Central, Barcelona, Valencia, Salamanca, Santiago, etc.) lo hayan completado considerablemente, el libro de PESET, Mariano y PESET, José Luis: La Universidad española (siglos XVIII y XIX). Despotismo ilustrado y revolución liberal, Madrid, Taurus, 1974. Ver también Peset, J. L., GARMA, S. y PÉrez Garzón, J. S.: Ciencias y enseñanza en la revolución burguesa, Madrid, Siglo XXI ed., 1978, y los dos volúmenes editados por el CIREMIA (Tours): L'Université en Espagne et en Amérique latine du Moyen-Age à nos jours. I.-Structures et Acteurs y II. Enjeux, contenus; images, Tours, Publications de l'Université de Tours, 1991 y 1998. Fondos archivísticos, someros resúmenes sobre la evolución de las facultades y bibliografía, en CARMONA DE LOS SANTOS, M.: Guía de fondos de Instituciones Docentes. Arcbivo Histórico Nacional, Madrid, MEC, 1999. 
nal, derecho penal, elocuencia forense y parlamentaria, entre otras muchassustentáculo todas ellas del liberalismo gobernante ${ }^{11}$, mucho antes de que llegasen a institucionalizarse en el espacio universitario oficial y, en fin, ya más adelante, en la avanzadilla del pensamiento social y de sus nuevos métodos, según veremos.

Por último, en cuanto Círculo literario y artístico, Labra compara en 1878 el Ateneo madrileño con su homónimo londinense The Athenaeum, entidad nacida en 1824 y lanzada en muy poco tiempo a una envidiable prosperidad, con palacio propio, una gran biblioteca, un completísimo gabinete de lectura y lujosos salones y restaurantes, al servicio de numerosos londinenses devotos de la lectura, aficionados a las letras y las artes así como amantes de la buena vi$\mathrm{da}^{12}$. Es cierto que nada de este lujo podían siquiera hacer imaginar el lóbrego caserón de la calle de la Montera y los sobrios salones de la institución madrileña anteriores a su sede de la calle del Prado. Tampoco tenía aquél nada del "pensamiento vivo que nace, se funde y perfecciona en el yunque de los discursos y de la contradicción», en el «espíritu de polémica que tanto caracteriza la manera de ser de la cultura latina», estilo cultural tan bien representado en el Ateneo madrileño ${ }^{13}$. Pero en todo caso, ambos compartían la característica sociológica de institucionalizar en entidades acordes con el nuevo siglo, es decir alejadas de los Salones y coffeehouses del pasado siglo, y al nuevo público que demandaban las actividades artísticas liberadas de los viejos controles académicos y de los tradicionales círculos de demanda artística. Ambos compartían además otro rasgo: el de abastecer sin medida, en forma de gabinetes de lectura y bibliotecas - común por lo demás a todos los ateneos- la desordenada sed de cultura letrada de las primeras élites liberales, la cualidad que les había convertido en individuos "razonantes» en posesión del orden natural del progreso y de las sanciones de la opinión pública:

Pero aún hay otro aspecto de la constitución ateneísta, que integra orgánicamente las anteriores, puesto que remite al espíritu de sociabilidad «raciocinante» de la época de su nacimiento ${ }^{14}$ : el de ser un conglomerado - de hombres, de culturas, de ideologías, de mentalidades- de su época. La nómina de sus «hombre ilustres» aglutina en efecto a «todos los hombres ilustres de España»; sus inquietudes, las de las grandes tareas abiertas durante mucho tiempo a

11 La investigación más sobresaliente a este respecto es la de GARrorena MORALES, A.: El Ateneo de Madrid y la teoría de la monarquia liberal (1836-1847), Madrid, Instituto de Estudios Políticos, 1974.

12 Ha publicado la historia de esta institución Cowell, F. R.: The Athenaeum: club and social life in London, 1842-1974, London, Heinemann, 1975.

13 González Serrano, Urbano: «El Ateneo de Madrid», en Estudios Críticos, Madrid, Esc. Tip. del Hospicio, 1892, p. 41. Ver también Labra, Rafael $\mathrm{M}^{\mathrm{a}}$ de: El Ateneo de Madrid. Sus orígenes, op. cit., pp. 12-13.

14 Conservamos el término «raciocinante» recogido en la traducción de la obra citada de Habermas. Sobre el espíritu de sociabilidad de la época, ver ZOZAYA MONTES, María: El Casino de Madrid, orígenes y primera andadura, Madrid, Casino de Madrid, 2002, pp. 40-43. 
los mentores del movimiento liberal; su papel, el de «director de la vida mental española». «No cabe —concluía Manuel Azaña- mayor compenetración entre un organismo y su época» ${ }^{15}$.

Esta particular concordancia fue lo que confirió su más acusada personalidad al Ateneo de Madrid de la primera época, al vincularle estrechamente a las vicisitudes políticas del primer liberalismo tanto en sus preocupaciones intelectuales como en la orientación ideológica imperante en su seno, de la que fue un fiel reflejo, sólo que a contracorriente de las tendencias dominantes en el gobierno de la nación, es decir, actuando como casa de oposición al partido liberal gobernante, conforme señala Antonio Ruiz Salvador ${ }^{16}$. Así, será progresista en la larga etapa de gobierno moderado, moderado en la corta experiencia progresista entre 1854 y 1856, y llegará a ser la representación del nuevo espíritu modernizador del liberalismo en los años precedentes a la Revolución de 1868 hasta que, producida ésta, los más destacados ateneístas sustituyan la labor doctrinal de sus cátedras por los despachos ministeriales, dejando aquéllas a los moderados desplazados del poder. Ya en la época de la Restauración se rompe relativamente esta correspondencia orientándose hacia derroteros más acordes con la pluralidad de tendencias de la cultura y la política.

Sin embargo, más allá de la coyuntural sintonía política y de sus posteriores derroteros es aquella omnipresente perspectiva sobre el medio y la época lo que resulta especialmente relevante en estas instituciones y lo que les hace llenar un hueco insustituible en la sociología de las instituciones científicas y culturales de la España liberal. En la evolución cultural contemporánea, la ciencia, la enseñanza, la literatura y el arte - sus ambiciosos objetivos programáticos de primera hora - van encontrando instituciones y formas de organización cultural específicas. Los centros universitarios se asientan definitivamente en los sistemas educativos nacionales del liberalismo y poco a poco van entrando en una etapa de permeabilidad y renovación científicas. En el terreno artístico, el mundo editorial, el régimen de Exposiciones públicas o privadas, el propio periodismo comenzarán a ofrecer perspectivas cada vez más sólidas para el creador, es decir comienza el proceso de institucionalización - centros, mercados, mecanismos de valoración y promoción- de los campos académicos y artísticos. Pero de todos estos medios, ninguno puede sustituir a los ateneos en la tarea de poner en relación el pensamiento y el arte, la reflexión política y la investigación erudita, el debate doctrinal y la emoción poética, la labor profesional de los hombres de cultura y la atención de la opinión pública, en un permanente ejercicio de integración de todas las energías intelectuales y de testimonio de todas las inquietudes intelectuales contemporáneas.

is AZAÑA, Manuel: Memoria leída en el Ateneo de Madrid por el Secretario $1^{\circ}$ D. -- el 11 de noviembre de 1913, Madrid, 1913, recogida en VILlacorTA BAÑos, Francisco: «Azaña y el Ateneo», op. cit., p. 431

16 Además de su obra ya citada sobre el Ateneo, ver sobre la etapa anterior a 1868 RUIZ SALVADOR, Antonio: «El Ateneo de Madrid antes de la Revolución de 1868», en LIDA, C. E y ZABALA, I. M.: La Revolución de 1868. Historia, pensamiento, literatura, New York, Las Américas, 1970, pp. 209-233.

Hispania, LXIII/2, núm. 214 (2003) 415-442 
Así se manifiesta incluso, más allá del ámbito de la cultura convencional, en el terreno de las prácticas culturales informales y de las necesidades de sociabilidad lúdica de los hombres de cultura (círculos, tertulias, bohemia), escenarios con frecuencia fútiles, pero que son consustanciales al desarrollo de los rituales identitarios y representativos del artista contemporáneo. El Ateneo de Madrid inventó para tales prácticas un conjunto de escenarios simbólicos (los centros de las tertulias y discusiones informales, para oponerlos a los escenarios de la disertación doctrinal, el Senado de la Montera, el salón de conferencias del Prado) de gran atractivo para esta forma de inteligencia diletante: el $W a$ gón, la Cometa, la Cacharrería del Ateneo de la Montera, la Cacharrería del nuevo edificio de la calle del Prado ${ }^{17}$. Famosas serán más adelante en el mismo sentido las penyes del barcelonés, centros de cultura oral, de actualidad ciudadana y de modas estéticas, influyentes sobre el conjunto de la vida barcelonesa ${ }^{18}$; en definitiva, escenarios todos de una idiosincrasia de café grande, "culto y desde luego con algunas ventanas a Europa», como decía Unamuno ${ }^{19}$, pero de la misma naturaleza inquieta, bulliciosa y a veces provocativa del resto de las tertulias, cafés, redacciones de los periódicos y tantos otros espacios de sociabilidad y reconocimiento de la nueva vida intelectual y artística del siglo XIX.

\section{GEOGRAFÍA Y MODALIDADES DE LA DIFUSIÓN}

No hace mucho, José Luis Sánchez García, que ha dedicado parte de sus tareas investigadoras a los Ateneos de Palencia y Valladolid, ha trazado un valioso cuadro-resumen del estado actual de nuestros conocimientos y de la difusión de esta modalidad ateneísta que venimos mencionando ${ }^{20}$. Dado el carácter necesariamente sintético del presente trabajo, nos remitimos a su estudio para una información más precisa sobre las pistas, no siempre evidentes, de los ateneos provinciales.

Al Ateneo de Madrid, y conforme a su modelo cultural, siguieron los ateneos de León, Cádiz, La Coruña, Badajoz, el Catalán (nace en 1860 como Ateneo Catalán, y en 1872 se fusiona con el Casino Mercantil de Barcelona para

17 Ver García Martí, V.: El Ateneo de Madrid 1835-1935, Madrid, Dossat, 1948, pp. 113-140 (descripciones tomadas fundamentalmente de LABRA, Rafael $\mathrm{M}^{\mathrm{a}}$ de: El Ateneo de Madrid, op. cit., y de SOlSONA, C.: «El Ateneo de Madrid», en Notas humorísticas, Madrid, Luis Navarro, 1882, pp. 45-59), y LEDESMA MIRANDA, R: El Ateneo en su antiguo marco: ambiente, ideas y figuras, Madrid, Ateneo, 1961.

18 Sobre esta etapa del Ateneo Barcelonés, entre 1908 y 1939, ver CASASSAS I YMBERT, Jordi: L'Ateneu Barcelonès. Dels seus orígens als nostres dies, Barcelona, Edic. de la Magrana, 1986, pp. 92-140.

19 UNAMUNO, Miguel de: «La evolución del Ateneo de Madrid», op. cit., p. 370.

20 SÁNCHEZ GARCÍA, José Luis: "Ateneísmo y ateneos en España», en La voluntad regeneracionista. Esfuerzo e inercia del Ateneo de Valladolid, 1872-1936, Palencia,. Región Editores, 1998, pp. 3-23. 
crear el definitivo Ateneo de Barcelona ${ }^{21}$ ), Valencia, el Balear, Zaragoza, Santander, Córdoba, Vitoria, el Menorquín, Ciudad Real, Huesca, Santiago de Compostela, Almería, Málaga, Valladolid, Lorca, Palencia, Toledo, Guadalajara, Avvila, Murcia, Castellón, el Riojano, Alcalá de Henares, Ferrol, Albacete, Béjar, Tarragona, Alicante, Soria, Sevilla, Teruel, Segovia, Jerez de la Frontera, el Tinerfeño, La Laguna, Cáceres, Bilbao, Salamanca, el Guipuzcoano, Vigo, Medina del Campo, Burgos, Zamora, el Navarro, Orense, Granada, Huelva, Cartagena y Las Palmas, los últimos ya en fechas avanzadas del siglo XX, en la coyuntura de la II ${ }^{a}$ República.

Todos ellos, junto al resto de modalidades ateneístas no contempladas aquí, componen, según la minuciosa recopilación de este estudioso, una extensa red superior al medio millar de centros de cultura de diversa índole bajo el rótulo general de «Ateneo». Todos ellos, por lo demás, instituciones de cultura urbana, acordes con el componente social predominante en sus asociados y de sus públicos, aunque no falten algunos emplazados en pequeñas villas de tipo semiurbano ${ }^{22}$. No todos los mencionados tuvieron una vida larga y fructífera, sin lugar a dudas. Menos aún han pervivido hasta nuestros días ni todos poseen el correspondiente estudio monográfico, al que serían acreedores ${ }^{23}$. Pero en conjunto, no cabe duda de que constituyen una atalaya privilegiada sobre el pano-

21 La crítica de SÁNCHEZ GARCíA («Ateneismo y ateneos en España», op. cit., p. 20) a la pretendida singularidad del ateneísmo catalán, que señala Bosch DATZIRA, A.: Els Ateneus de Catalunya, 1854-1990, Barcelona, Federació d'Ateneus de Catalunya, 1991, nos parece acertada.

22 Sánchez García, José Luis: El Ateneo Científico, Literario y Artístico de Palencia (18761926), Palencia, 1989, pp. 42 y 52, hace un interesante recuento de la composición social, profesional e ideológica de los asociados, tanto del Ateneo Vallisoletano como del Palentino. También para el de Vitoria, su estudioso Reboredo Olivenza, J. M.: El Ateneo Científico, Literario y Artístico de Vitoria (1866-1900), Vitoria, Diputación Foral, 1988, pp. 113-126, proporciona numerosos datos biográficos acerca de sus principales animadores. Ver igualmente ÑACLE GARCíA, A.: El Ateneo Albacetense, 1880-1993, Albacete, Caja Castilla-La Mancha, 1993, pp. 221-248, sobre sus presidentes.

23 Aunque se pueden rastrear noticias sobre estas instituciones en las guías urbanas, en biografías y memorias personales y en historias particulares de la mayor parte de las ciudades españolas, algunas han merecido estudios monográficos más o menos recientes. Destaquemos, además de los ya mencionados hasta aquí, los siguientes: Simón CABARGA, J.: Historia del Ateneo de Santander, Madrid, Editora Nacional, 1963; CASTILLO GenZOR, A.: El Ateneo de Zaragoza (112 años al servicio de la cultura popular), Zaragoza, Ed. La Cadiera, 1976; PERAZA DE AYALA, I.: Ensayo de historia del Ateneo de La Laguna desde su fundación en 1904 basta finales de 1936, Tenerife, Cabildo Insular, 1979; TORibio RuIz, R. M.: El Ateneo Jerezano, Jerez de la Frontera, Edit. Sexta, 1981; PABlo-Romero DE LA CÁmARA, M.: Historia del Ateneo de Sevilla, 1887-1931, Sevilla, Colegio Oficial de Aparejadores y Arquitectos Técnicos, 1982; CIENTO veinticinco años de cultura en Cádiz a través de su Ateneo Literario, Artístico y Científico (1858-1993), San Fernando, 1985; LlORCA FreIRE, G.: Os Ateneos ferrolans na sua historia (1879-1936), La Coruña, 1985; SANS ORENGA, M.: Breu bistòria de l Ateneu Barcelonès... Barcelona, $2^{a}$ ed., 1987; RAmos, V.: Breve bistoria del Ateneo de Alicante, Alicante, Ateneo C., L. y A. de Alicante, 1992; SORIA ANDREU, F.: El Ateneo de Zaragoza (1864-1908), Zaragoza, Institución Fernando el Católico, 1993; NAvajas Zubeldía, C. y ANDrés Cabello, S.: El Ateneo Riojano o la «casa de todos» (1922-1998), Logroño, Instituto de Estudios Riojanos, 2001.

Hispania, LXIII/2, núm. 214 (2003).415-442 
rama de la cultura pública de la España contemporánea y sobre sus hombres más sobresalientes.

\section{ADAPTARSE AL TIEMPO. LA «RESTAURACIÓN» CULTURAL}

Si como hemos indicado más atrás, la matriz esencial de los ateneos es su estrecha sintonía con su tiempo y con su medio social, nada tiene de extraño que también ellos adopten los particulares cambios ligados a la «restauración» política canovista. Estos cambios responden en su sentido más general a una particular circunstancia institucional (nuevas instituciones) y sociológica (nuevos públicos) de la cultura española, que obliga necesariamente a replantear la organización interna de sus actividades ateneístas en la forma en que habían quedado plasmadas en sus primeras etapas. El sentido particular de esas transformaciones viene señalado en primer término por el establecimiento de un marco asentado de libertades públicas -innegable a pesar de su tendencia moderada y de su práctica corrupta-, lo que reduce el margen de maniobra de los ateneos - del Ateneo de Madrid desde luego, del resto de los ateneos con mucha frecuencia - como refugios de la conciencia pública liberal, más o menos implicados activamente en las luchas partidistas.

La acción política, podríamos decir, aun con todas sus limitaciones, cobra carta de naturaleza en los espacios públicos que le son propios, en tanto que las entidades culturales se repliegan sobre el marco institucionalizado de desenvolvimiento intelectual. Ya no es el Ateneo — señalaba Manuel Azaña en 1913 sobre el de Madrid- aquel producto específico del primer tercio del siglo XIX, empeñado "en la idea de una cultura independiente», aquel «reducto de libertades públicas, incorporadas de modo definitivo a la vida española» ${ }^{24}$. Por el contrario, única renovación posible de su función cultural, había de desarrollarse ahora a través de un cambio de objetivos: el de activar las inquietudes científicas modernas y el conocimiento especializado de la juventud universitaria, el de dar satisfacción a la tarea de «formarse», que era el estereotipo novísimo de la emulación juvenil, como otrora fue el de «llegar», no se sabía muy bien a dónde aunque se suponía que a un Ministerio, según decía Unamuno25; la misma tarea que ha podido inspirar la afortunada metáfora del viejo caserón «situado simbólicamente alrededor de una Biblioteca», que por su importancia y atractivo bien puede ser considerado "granero» intelectual y pósito histórico de las ciencias sociales españoles ${ }^{26}$.

24 AZAÑA, Manuel: Memoria leída en el Ateneo de Madrid, op. cit., pp. 431-432.

25 UNAmuno, Miguel de: «La evolución del Ateneo de Madrid», op. cit., p. 367.

26 DuQUE, I.: «El momento fundacional de las ciencias sociales españolas contemporáneas y el Ateneo como crisol, escena y pósito: paradojas y perspectivas de su horizonte teórico, investigaciones concretas e intervención social reformista», en Centenario de la Información de 1901 del Ateneo de Madrid sobre Oligarquía y Caciquismo, Madrid, Ateneo de. Madrid-Ed. Fundamentos, 2002, p. 305. 
Ya los coetáneos de sus etapas más cercanas lo contemplaban así, como un centro privilegiado en la economía de la supervivencia de la juventud estudiosa llegada a la capital, el lugar donde por una pequeña cuota se le proporcionaba libros para el estudio, calor, bohemia y, concluida la carrera, una buena biblioteca donde preparar oposiciones y solucionar indefinidamente el problema de la subsistencia a expensas del erario público ${ }^{27}$. Esta evolución, que está perfectamente documentada en el caso del Ateneo de Madrid es la que sufren también el resto de los ateneos tempranos, como el de Zaragoza, órgano del partido democrático antes del 68 y desde la Restauración sujeto de la misma diversificación de intereses culturales que resulta observable en el madrileño. En los ateneos más tardíos esta adaptación está incluso implícita en las propias circunstancias de su nacimiento:

Todo ello no contradice el hecho de que, allí donde estén, los ateneos sean en todo momento atalayas avanzadas sobre las cuestiones políticas y sociales más candentes de la vida nacional o local y que recuperen ocasionalmente una acentuada tonalidad política cuando las circunstancias de ese campo traigan a primer plano la exigencia de un compromiso activo. Tal será el caso del Ateneo de Madrid, que experimenta a lo largo del siglo XX una activa implicación en las polémicas político-culturales del siglo, de la mano precisamente del propio Manuel Azaña desde el puesto de Secretario $1^{\circ}$. Participa en la campaña por la laicidad de la enseñanza, difunde las ideas políticas del radicalismo liberal europeo, se encuentra implicado en la enconada polémica entre germanófilos y aliadófilos y, cuando en 1923 ha constituido una comisión pro-responsabilidades por el desastre de Annual, paralela a la homónima Comisión Parlamentaria e intenta implicar en ella al resto de los ateneos provinciales, siente fiscalizada su tradicional libertad por la dictadura de Primo de Rivera, que cierra momentáneamente sus salones y destierra a algunos de sus más preclaros socios, Unamuno y Rodrigo Soriano entre ellos.

El Ateneo fue en esta coyuntura política un incómodo caso, de molesta actualidad y difícil resolución, que la Dictadura no logró resolver con la apertura de sus salones en régimen de tutela gubernativa. En el interregno dictatorial de 1930-1931, la institución se puso a la cabeza del movimiento cívico de recuperación de las libertades públicas y adoptó, con Manuel Azaña a la cabeza, una orientación claramente republicana. En sus salones se reunía el Comité Revolucionario organizado tras el Pacto de San Sebastián de 1930 y en ellos se vivieron intensamente los preliminares de la rebelión de Jaca en noviembre de ese año, en la que participó una brigada de socios ateneístas ${ }^{28}$.

Cerrado finalmente tras esta intentona republicana, retornó con el 14 de abril como abanderado del nuevo régimen. Con razón podría decir Giménez

27 CÁNOVAS CERvantes, S.: Apuntes históricos de «Solidaridad Obrera», Barcelona, s.f., pp. 100-101.

28 TUÑ́́N DE LARA, Manuel: «La sublevación de Jaca», Historia 16, 1, mayo de 1976, pp. 57-64.

Hispania, LXIII/2, núm. 214 (2003) 415-442 
Caballero meses más tarde que toda la España republicana «olía a Ateneo»29. Pero de este clima de agitación salió también un Ateneo decididamente inclinado hacia posiciones extremistas - no necesariamente de izquierda revolucionaria- que participó vivamente en los principales conflictos del régimen republicano y que entró en conflicto con su presidente, Manuel Azaña ${ }^{30}$.

No en todos los casos, sin embargo, la respuesta de los ateneos a los estímulos de la vida política se manifestó acorde con este modelo del Ateneo madrileño, que fue único en lo que tenía de irrepetible por su posición geográfica en el corazón del poder estatal y por su capacidad de resonancia ante la opinión pública nacional e internacional. Pero en todos los casos, a despecho de cualquier voluntad programática, estas instituciones serán la expresión de un interés más extenso que el científico o profesional al que pudieran remitir sus actividades culturales: serán el eco de una conciencia cívica proyectada sobre el conjunto de los asuntos públicos de la comunidad política nacional o local. El resto: - su mayor o menor implicación directa en la política nacional o local-, en sus momentos más críticos, será el resultado de un conjunto imprevisible de adaptaciones particulares a las circunstancias concretas o, de forma más general, a las coyunturas intelectuales más o menos propensas a la inflexión política de la cultura, como fue el caso de los años 30 del siglo XX.

El Ateneo Barcelonés, el de Palencia, el Riojano, el de Valladolid, el de Albacete, el de Alicante - los mejor documentados en las etapas ateneístas más próximas - se vieron inmersos de distinta forma en esas particulares crisis, con estrategias y resultados diversos: camuflarse, contemporizar, resistir, exaltarse o también abandonar, formas diversas de sobreponerse a unos factores de evolución que escapaban a las funciones culturales estrictas con que habían surgido y que, por supuesto, caían fuera de su control. Así lo hicieron en la época de Primo de Rivera, en la $\mathrm{II}^{\mathrm{a}}$ República y así abordarán el mucho más problemático periplo posterior, a veces como institución incautada por el poder público (Ateneo de Barcelona), a veces como centro de propaganda cultural de la Alianza de Intelectuales Antifascistas para la Defensa de la Cultura (Ateneo de Alicante), a veces como camuflaje cultural del falangismo o, ya más adelante, como espacio neutro del ritual cultural, a veces simplemente enmudeciendo. En todos estos episodios apenas se puede hablar estrictamente de ateneísmo, aunque formen parte en sentido estricto de su historia institucional.

Con independencia de esta dimensión pública de la cultura ateneísta, las transformaciones experimentadas en el transcurso del siglo afectaron al conjunto de su estructura institucional. En primer término, a sus actividades educativas regulares. Centrándonos de nuevo en el Ateneo de Madrid, el propio Labra,

29 Giménez Caballero, E.: Manuel Azaña. Profecías españolas, Madrid, Edic. de La Gaceta Literaria, 1932, p. 124.

30 Ruiz Salvador, A.: El Ateneo, Dictadura, República, Valencia, Fernando Torres, 1976. También, para la etapa de la secretaría azañista, Ver VILLACORTA BAÑOS, F.: Burguesía y cultura. Los intelectuales españoles en la sociedad liberal, 1808-1931, Madrid, Siglo XXI, 1980, pp. 128-140.

Hispania, LXIII/2, núm. 214 (2003) 415-442 
en su primer recuento histórico de la institución, nos descubre las limitaciones de un centro al que considera en mayor medida más instrumento de intereses particulares que fuente de verdadero saber:

«En el Ateneo siempre tendrán preferencia los discursos brillantes, los trabajos de pura propaganda, los estudios de aparato, resintiéndose la enseñanza regular y metódica. Casi me atrevo a decir que ésta no existe, ni ha existido ni existirá mientras el profesorado no tenga retribución».

Significaría aquella enseñanza metódica - nos cuenta Labra- enlazar con los primeros tiempos ateneístas sobre bases nuevas, tal como lo proyectó Francisco Giner de los Ríos en 1865, al proponer el establecimiento de cátedras de enseñanza en las disciplinas de Política, Derecho, Filosofía de la Historia, Historia de la Filosofía Española y Estética, con un profesorado reclutado por oposición y con matrícula anual. O, si se quiere, según el proyecto de Fermín Gonzalo, con cátedras públicas con retribución mensual y reserva del 25 por 100 de la matrícula para el fondo de biblioteca. Trece años más tarde, en 1878 , todavía espera Labra que alguno de estos proyectos pueda realizarse y que el Ateneo llegue a ser "por sus propios recursos o mediante inteligencias con alguna otra corporación tal como la Institución Libre de Enseñanza, la gran Universidàd Libre de España» ${ }^{31}$.

$\mathrm{El}$ ateneísmo, que durante bastantes años pudo jugar prioritariamente como contrapunto a la realidad educativa de las instituciones públicas, quedaba así emplazado, pasado el tiempo, en su punto crítico de resolución $\longrightarrow$ institución cultural que podríamos denominar generalista o centro educativo superior- por un hombre como Labra, que fue agente activo directo, aparte de historiador, de un buen número de iniciativas de renovación cultural y pedagógica de la España del siglo XIX ${ }^{32}$. Más adelante, según veremos, se ensayará la solución de la Escuela de Estudios Superiores.

En contraste con estas hipotéticas perspectivas, dos innovaciones presenta el cuadro de actividades del Ateneo madrileño en los primeros años de la Restauración. La primera son las veladas poéticas que comienzan a organizarse a partir de 1876. En el curso 1876-1877, se discutió en la sección de Literatura sobre el estado actual de la poesía lírica en España y como consecuencia de ello se invitó a algunos poetas coetáneos a leer sus versos en el Ateneo. Zorrilla, Campoamor, Núñez de Arce, Selgas, Fernández y González, Ruiz Aguilera, Palacio y otros lo hicieron aquel año. El éxito de la innovación fue tan grande que se repitió en los años siguientes y llegará a ser un elemento característico

31 LABra, Rafael Ma de: El Ateneo de Madrid. Sus orígenes, op. cit., pp. 196-197.

32 Datos sobre esta faceta de la vida intelectual y política de Labra en ERICE, Francisco: «Reformismo social, Krausismo y Republicanismo: la cuestión social en Rafael María de Labra», en URíA, Jorge (Ed.): Institucionismo y reforma social en España. El grupo de Oviedo, Madrid, Talasa, 2000, pp. 79-106. 
de las posteriores etapas ateneístas. Ya en el curso 1879-1880, escribe Antonio Sánchez Moguel que, por contraposición a la languidez de las cátedras y secciones, «en el movimiento literario y artístico se viene alcanzando singular progreso de algunos años acá. Puede decirse que todo lo que en un sentido decae el Ateneo, en otros se levanta. Y que esto se debe a las lecturas literarias, asegúralo la opinión unánime de los ateneístas y de personas extrañas al Ateneo»" ${ }^{33}$.

Innovación en apariencia desdeñable, pero que, unida a otra que se produce paralelamente, parece indicar una nueva orientación, o tal vez mejor, un proceso de reasentamiento en el nuevo tablero institucional de la cultura y de la opinión pública en el último cuarto de siglo. Esta segunda innovación la expresa Labra así: en el año 1878, el Presidente del Ateneo (entonces José Moreno Nieto) invitó a un «grupo de oradores para que ocupasen la cátedra dando algunas de esas conferencias que con tanto éxito inauguró la Institución Libre de Enseñanza en 1877, y que tan en boga han puesto el Círculo de la Unión Mercantil, el Fomento de las Artes, el Ateneo Mercantil, la Dirección de Agricultura, el Conservatorio de las Artes y la Sociedad Económica Matritense» ${ }^{34}$.

Se comenzaron, por lo tanto, a dar este tipo de conferencias y, «aunque con poco éxito» en un principio, según Ruiz Salvador ${ }^{35}$, serán verdaderamente la auténtica sabia ateneísta a partir de entonces en sustitución de las ya agotadas cátedras en el sentido tradicional. «La conferencia pública - decía Becerro de Bengoa por la misma fecha- es una imposición de nuestro siglo; en vano es atacarla, desprestigiarla, odiarla o escarnecerla; se ha impuesto en los grandes centros, se ha extendido en las ciudades secundarias, lo invade todo y todo lo avasalla» ${ }^{36}$. Lejos, pues, de constituir un mero retoque de formato académico, respondía, sin duda, a un cambio significativo en la constitución del espacio público, mucho más extenso y receptivo que en las etapas iniciales del liberalismo, en una coyuntura, como decía Labra, en que el camino de la cultura cívica comenzaba a desbrozarse, más que en la socrática dialéctica entre pares, en el de la conquista de la opinión pública a través del movimiento político, la prensa y el trato internacional ${ }^{37}$.

En ocasiones, un grupo de conferencias sucesivas sobre el mismo tema tiende a cubrir la apariencia de que la enseñanza ateneísta continúa vigente, y ciertamente así podría interpretarse siempre que se le asigne la modalidad del curso monográfico de la enseñanza académica moderna. Pero hacerlo así implica ya derivar implícitamente el flujo de los contenidos culturales ateneístas hacia el cauce general de la cultura científica difundida en las instituciones

33 SÁnCHez Moguel, A.: "El Ateneo de Madrid en el año académico de 1879-80», Revista Contemporánea, Madrid, t. 28, Junio de 1880, p. 86.

34 Labra, Rafael María de: El Ateneo de Madrid. Sus orígenes, op. cit., p. 175.

35 Ruiz Salvador, Antonio, El Ateneo Científico, literario y artístico de Madrid, op. cit., p. 149.

36 Becerro de Bengoa, Ricardo, citado por SÁnChez García, José Luis: El Ateneo de Palencia, op. cit., p. 116.

37 LABRA, Rafael Ma de: El Ateneo de Madrid. Notas bistóricas, op. cit., p. 3. 
educativas superiores y hacia los nuevos procedimientos y métodos que comienzan a imperar en el estudio de sus disciplinas.

La línea fronteriza que separa el campo de una cultura ateneísta (como aportación intelectual propia, identificativa de un estilo doctrinal y de una casi completa libertad de cátedra que se le ofrecen en los primeros años de su vida en virtud de una serie de circunstancias políticas e institucionales de la creación y difusión cultural del primer liberalismo) y el que ofrecen las nuevas corrientes y especialidades científicas que comienzan a despuntar aquí y allá en conferencias, discursos, academias oficiales, cátedras universitarias, revistas o publicaciones, abanderadas por profesionales y expertos ya firmemente asentados en los puestos de la burocracia académica oficial, aparece perfectamente delimitada a partir de estos momentos y, como consecuencia de ello, la inevitable realineación del papel relativo del ateneísmo en el marco de todos esos espacios de la cultura nacional. Ese alto papel seguirá perteneciéndole en un sumo grado, pero sólo a partir de lo que ha sido y de lo que representa, como un efecto derivado del prestigio y de la resonancia que en el marco de todos aquellos espacios de difusión cultural reserva la Docta Casa, el ateneísmo, a los verdaderos protagonistas - creadores, científicos, divulgadores- que han pasado así, a través de todos estos cambios, a primera fila de nuevos campos sociales donde se despliega el juego de la apropiación de los recursos culturales, del reconocimiento, del prestigio, la difusión, la innovación, etc.; campos sociales institucionalizados, pues, de forma cada vez más compleja, del que los ateneos son sólo una - aunque importante- pieza.

En esta nueva situación del marco cultural institucionalizado, otras varias iniciativas de la vida interior ateneísta van a cobrar una creciente importancia, junto a las conferencias y ciclos monográficos mencionados. Así, en el curso 1880-1881 se conmemora en el Ateneo de Madrid el segundo centenario de la muerte de Calderón de la Barca, que da lugar a una nueva experiencia cultural. Recogidos los actos celebrados con ocasión de la efemérides en un folleto titulado El Ateneo de Madrid en el Centenario de Calderón. Disertaciones, poesías y discursos de los señores Sánchez Moguel, Revilla, Ruiz Aguilera, Fernández y González, Palacio, Campillo, Moreno Nieto, Moret y Echegaray (Madrid, 1881), "parecen ser - dice Ruiz Salvador - el primer ensayo ateneísta de tratamiento colectivo de un tema» ${ }^{38}$, aparte el significado que a este tipo de celebraciones se le ha atribuido en la consolidación de los cánones y rituales identitarios de la cultura nacional ${ }^{39}$.

38 RuIz Salvador, Antonio: El Ateneo científico, literario y artístico de Madrid, op. cit., p. 151.

39 Ver al respecto, con carácter general, los recientes trabajos de PÉREZ GARZÓN, J. S., MANZANO MORENO, E, LÓPEZ FACAL, R. y RIVIÈre GÓMEZ, A.: La gestión de la memoria. La historia de España al servicio del poder, Barcelona, Crítica, 2000, y ÁlvareZ JunCO, J.: Mater Dolorosa. La idea de España en el siglo XIX, Madrid, Santillana, 2001. Más en concreto, STORM, E.: «El tercer Centenario de Don Quijote en 1905 y el nacionalismo español», Hispania. Revista Española de Historia, Madrid, LVII/2, 199, 1998, pp. 625-654.

Hispania, LXIII/2, núm. 214 (2003) 415-442 
Estas iniciativas académicas tendrán importantes continuaciones en los años siguientes, entre las cuales las más conocidas son las conferencias de $\mathrm{La}$ España del siglo XIX, vasto panorama de la historia del siglo XIX español encarnada en los hombres paradigmáticos de cada uno de las temas analizados ${ }^{40}$, la información de 1895, patrocinada por Joaquín Costa, sobre Tutela de pueblos en la bistoria ${ }^{41}$, la de 1901-1902, bien conocida, del propio Costa sobre Oligarquía y Caciquismo, y la de 1902 sobre las costumbres populares españolas en torno al nacimiento, matrimonio y muerte, estas últimas enmarcadas en el impulso finisecular, que hizo del conocimiento histórico y antropológico del pueblo español uno de sus mitos regeneradores ${ }^{42}$. Y por supuesto, las vinculadas coyunturalmente a efemérides culturales, políticas o históricas como centenarios (descubrimiento de América, Mozart, Bartolomé Leonardo de Argensola, El Quijote, los Sitios de Zaragoza, la Constitución de Cádiz, etc.), homenajes, certámenes literarios, exposiciones, etc. Actividades todas compartidas por los ateneos provinciales ${ }^{43}$, adaptadas ocasionalmente a los incentivos de la política y de la cultura local, aunque indudablemente sin la capacidad de convocatoria del Madrileño ni su posición avanzada en la vanguardia de las nuevas disciplinas científicas y de sus métodos que reflejan las encuestas de 1901-1902.

En resumen, unas y otras novedades - conferencias sueltas, cursos monográficos, informaciones, encuestas, centenarios - junto con las veladas artísticas, se unirán o sustituirán en los años sucesivos a las tradicionales actividades ateneístas y aportarán a la vida cultural una nueva personalidad y, lo que es más importante, un nuevo público, expresión de las demandas culturales de la sociedad cada vez más plural del último tercio de siglo; un público en el que, como nota específica de especial importancia, comienza a notarse la presencia femenina, habitual como oyente en las butacas y ya no excepcional como pro-

40 La España del siglo XIX, Madrid, Imp. El Liberal, 1886-1887, 3 vols.

${ }^{41}$ Sobre ella, ver VILLACORTA BAÑOS, F.: «Pensamiento social y crisis del sistema canovista, 1890-1898", en Fusi, Juan Pablo y NiÑo, Antonio (Eds.): Visperas del 98. Orígenes y antecedentes de la crisis del 98, Madrid, Biblioteca Nueva, 1997, especialmente pp. 254-256.

42 De entre las ediciones de la encuesta sobre Oligarquía y Caciquismo, destaquemos la de ORTí, A.: Información en el Ateneo de Madrid, 1901. Oligarquía y Caciquismo como la forma actual de gobierno en España. Urgencia y modo de cambiarla. Vol. I. CosTA, J.: Memoria de Sección y Resumen de la Información. Vol. II: Informes y Testimonios, Madrid, Edic. de la Revista de Trabajo, 1975. Resulta además imprescindible la obra recientemente publicada, conmemorativa de la citada encuesta: Centenario de la "Información de 1901", donde se ofrece un amplio e interesante panorama sobre el contexto, sobre el propio Ateneo y sobre la obra de Costa. En el artículo ya mencionado de I. DUQUE: «El momento fundacional de las ciencias sociales españolas", se traza un extenso análisis sobre la otra encuesta del Ateneo de la misma época, así como la bibliografía que hasta el momento ha generado. Sobre otras tradiciones pioneras del Ateneo de Madrid, ver DíEz TORRE, Alejandro R.: «El pasado revalorizado. Orígenes culturales y Arqueología en el Ateneo de Madrid, 1838-1918», El Ateneo, 4a época, VII, Diciembre de 1996, pp. 56-77.

43 Soria Andreu, F.: El Ateneo de Zaragoza, op. cit., pp. 203 ss, documenta pormenorizadamente algunas de estos homenajes y celebraciones.

Hispania, LXIII/2, núm. 214 (2003) 415-442 
tagonista en la tribuna. Sólo será cuestión de tiempo que esta presencia adquiera la mirada problemática del género, con la aparición de las primeras reflexiones sobre el papel de la mujer en diversos campos sociales ${ }^{44}$.

Frente a estos nuevos alineamientos culturales, también las actividades de discusión y análisis científico realizadas en el marco de las Secciones del Ateneo se resienten. Resulta por lo demás obvia la difícil adaptación de sus pretensiones cientifistas y enciclopédicas al molde de la cultura científica experimental que comienzan a poner en práctica en el siglo XIX las instituciones académicas especializadas. De nuevo, como antes se ha mencionado, la vida ateneísta en este terreno cobra sentido por relación al panorama general de la cultura científicoexperimental del momento, y en ese vínculo su posición resultaría mucho peor parada que en el de las ciencias sociales e históricas. Otra cosa es que no se intente una imposible adaptación.

Sin duda, la experiencia más destacada del Ateneo de Madrid a caballo entre los siglos XIX y XX fue precisamente la llamada Escuela de Estudios Superiores, caso singular no sólo entre el resto de instituciones ateneístas sino también entre el conjunto de centros de saber nacionales, concebida como una cátedra «dignificada y permanente» de saber integrado, teórico-experimental, y por lo que respecta al conjunto de esa cultura en el ámbito nacional, divulgadora -según decía su promotor, el político liberal y entonces presidente ateneísta, Segismundo Moret- de todo lo que de nuevo se creaba en el mundo en ese tipo de conocimiento y capaz de suplir las inevitables deficiencias de la enseñanza oficial ${ }^{45}$.

Por la Escuela pasaron, en efecto, durante una decena de años, entre 1896 y 1907, las figuras más representativas de la cultura científica y humanística de la España del momento. Considerada en su conjunto, conforma un amplio corte en la perpendicular de la cultura científica y erudita de la España del momento. En su marco se ensayó otra de las innovaciones científicas en boga en las instituciones académicas más avanzadas: el método de laboratorio o seminario experimental, con poco éxito en el caso de las ciencias experimentales puras a pesar de las permanentes referencias de los gestores ateneístas al carácter técnicoexperimental de las explicaciones, con material adecuado, incluso traído directamente del extranjero ${ }^{46}$, y a sus esfuerzos por obtener recursos con este fin.

Todavía en 1905, el entonces Secretario $1^{\circ}$, Mariano Miguel del Val, solicitaba al Ministerio de Instrucción Pública una subvención especial para montar

\footnotetext{
44 Ejemplo de ello, las actividades del Ateneo Zaragozano al respecto, que menciona SorIA ANDREU, F.: El Ateneo de Zaragoza, op. cit., pp. 69-70, o el curso sobre la obra de Concepción Arenal celebrado en el de Madrid en el curso 1892-1893, publicado en Madrid en 1894 con el título Doña Concepción Arenal en la ciencia jurídica, sociológica y en la literatura.

45 MORET, S.: Discurso pronunciado por el Excmo. Sr. D. -- el día 22 de octubre de 1896 en el Ateneo Científico, Literario y Artístico de Madrid con motivo de la apertura de.sus cátedras, Madrid, 1896.

46 Ateneo de Madrid. Escuela de Estudios Superiores, curso de 1897 a 1898, Madrid, 1897, pp. 64-66.
}

Hispania, LXIII/2, núm. 214 (2003) 415-442 
una cátedra de Técnica de Laboratorio ${ }^{47}$. Estas actividades fueron además el origen de las subvenciones presupuestarias a las actividades del Ateneo de Madrid; aplicadas inicialmente a las enseñanzas mencionadas y, una vez clausuradas, a diversos ciclos de conferencias agrupadas bajo el rótulo de «Conferencias organizadas por el Ministerio de Instrucción Pública y Bellas Artes», con temas de ordinario dedicados a la erudición literaria y artística. Más adelante, el Ateneo Riojano comenzará a recibir subvención del Ayuntamiento de Logroño ${ }^{48}$.

Algo más de éxito se tuvo en el campo de las ciencias teóricas, a juzgar por el alcance del Laboratorio de Economía Política del Ateneo de Madrid desarrollado por el profesor Antonio Flores de Lemus en los cursos 1904-1905, 19051906 y 1906-1907, y en el cual se pusieron en práctica los métodos de investigación del realismo económico germánico (de los que el sistema de laboratorio era precisamente un aspecto primordial) en los que el titular acababa de formarse en las Universidades de Tubinga y Berlín bajo el magisterio de los economistas Gustavo Schmoller y Adolfo Wagner ${ }^{49}$. También cabe citar el laboratorio del profesor Julio Cejador sobre Lingüística (1904-1905). Se proyecta además un Laboratorio de Criminología a cargo del penalista Pedro Dorado Montero, que no se llegaría a impartir. Recordemos que el Laboratorio de Criminología, antecedente de la Escuela de Criminología creada oficialmente en 1903, se había organizado inicialmente en 1899 en la cátedra de Filosofía del Derecho de Giner de los Ríos y confiado a Rafael Salillas ${ }^{50}$.

Por la misma época, los ateneos son receptáculo también de otras iniciativas culturales antes ensayadas en otros centros pioneros. Fueron, por ejemplo, las experiencias de extensión universitaria que había puesto en marcha en España el grupo institucionista de la Universidad de Oviedo - Posada, Álvarez Buylla, Altamira, Sela, Clarín, Aramburu, Canella ${ }^{51}$ _, según el modelo de la

47 Archivo del Ministerio de Educación y Cultura. AGA. «Subvenciones a establecimientos de enseñanza no oficial», leg. $\mathrm{n}^{\circ} 6652$.

48 Navajas Zubeldia-ANDRÉs Cabello: El Ateneo Riojano, op. cit., p. 99.

49 Viliacorta Baños, F.: El Ateneo Científico, op. cit., pp. 106-109, y GAY, Vicente: «El profesor Antonio Flores de Lemus", Moneda y Crédito, 8, 1944, pp. 8-13. El profesor Velarde FuerTES, J.: Introducción a la bistoria del pensamiento económico español del siglo XX. Madrid, 1974, pp. 111-147, da por concluida en febrero de 1905 la vinculación ateneísta de Flores de Lemus. La Escuela de Estudios Superiores, sin embargo, continúa colocándolo entre sus profesores durante dos cursos más.

so SÁNCheZ-Granjel Santander, G.: Pedro Dorado Montero, un penalista Salmantino, Ávila, Junta de Castilla y León, 1990, especialmente pp. 141-149. Sobre la Escuela de Estudios Superiores, sus cátedras, sus profesores y alumnado, así como sobre las corrientes del pensamiento social presentes en ella, ver VillacorTa BAÑos, F.: El Ateneo de Madrid, op. cit., pp. 97-128 y 289-300.

51 Sobre el grupo, ver el interesante trabajo ya mencionado de URÍA, Jorge (Ed.): Institucionismo y reforma social en España. Analizan aspectos particulares de la obra del grupo J. URÍA, J. S. PÉREZ Garzón, M. Suárez Cortina, E. Zimmermann, F. Erice, J. A. Crespo Cabornero, S. Castillo, Y. Lissorgues, A. Baratas, R. Campos Marún, C. García García Y A. Terrón Bañuelos. Ver también GuEREÑA, J.-L.: «Clarín en la Extensión Universitaria ovetense (1898-1901)», en Clarín y La Regenta en su tiempo, Oviedo, Universidad de Oviedo, 1987, pp. 155-176. 
extensión universitaria inglesa. Experiencias sustentadas a la vez sobre la creciente presencia social de mundo obrero y sobre las preocupaciones intelectuales por encauzar sus posibilidades de ocio (en el Ateneo de Palencia se llegó incluso a constituir una Sección Obrera ${ }^{52}$ ) se difundieron según el modelo ovetense en varias instituciones académicas y en algunos ateneos, en el de Sevilla como en el de Madrid, pero en todos los casos sin gran continuidad. En el Ateneo de Madrid, el programa duró cuatro años, entre 1904 y 1907, sufriendo el mismo tipo de inconvenientes en que se desenvolvieron en general este tipo de iniciativas, expresión más bien de un particular enfoque intelectual del problema obrero que de los intereses culturales específicos de sus destinatarios.

También en el Ateneo de Madrid prendió otra iniciativa cultural, esta vez de origen francés ${ }^{33}$, orientada hacia el mismo tipo de público: las universidades populares. Creada en 1904 en el Ateneo la Universidad Popular de Madrid por un amplio grupo de representantes de las profesiones intelectuales, durante unos pocos años llevó sus profesores y sus programas de animación cultural a diversos centros obreros madrileños, sin que la experiencia lograse completar la totalidad de sus ambiciosos proyectos iniciales ni finalmente superar la prueba de la realidad ${ }^{54}$.

Fueron, por último, las iniciativas de excursionismo cultural, de neta raíz institucionista de nuevo y vinculadas además a la revalorización de la cultura y del patrimonio locales. El caso más llamativo lo constituyó, sin duda, el Ateneo de Sevilla, nacido originariamente en 1887 por iniciativa del sociólogo Manuel Sales y Ferré como Ateneo y Sociedad de Excursiones, escindido del entonces Ateneo Hispalense con el objetivo de promover una nueva forma de contacto directo con los bienes públicos de la cultura. Otros ateneos especialmente tentados por esta modalidad cultural fueron los de Zaragoza, que lo estableció oficialmente en su reglamento de 1898, y el de Madrid, donde la Sociedad Madrileña de Excursiones promovió ciclos periódicos de conferencias sobre arte y patrimonio.

En concomitancia con estas líneas de evolución ateneísta, otro rasgo destacado de estos años fue el intento de proyectarlo también fuera del ámbito de sus socios y simpatizantes por medio de la letra impresa. Es necesario subrayar aquí la importancia de algunas de estas iniciativas emprendidas por ateneos

S2 SÁNCHez García, J. L.: El Ateneo de Palencia, op. cit., pp. 135-139.

53 Traza la historia de esta iniciativa en Francia el libro de MERCIER, Lucien: Les Universités populaires: 1899-1914. Education populaire et mouvement ouvrier au début du siècle, Paris, Ed. Ouvrières, 1986. Ver también su contribución «La educación popular a través de las Universidades Populares en la Francia de principios del siglo XX», en el monográfico de Historia de la Educación sobre Educación popular $\left(\mathrm{n}^{\circ} 20,2001\right)$.

${ }_{54}$ Proyectos y lista de fundadores en GASCÓN Y MiRAMÓN, A.: Memoria relativa a la fundación de la Universidad Popular de Madrid, Madrid, 1905. Ver MOReno MARTíneZ, Pedro Luis y SebaSTIÁN VICENTE, Ana: «Un siglo de Universidades populares en España (1903-2000)», Historia de la Educación, Salamanca, $\mathrm{n}^{\circ} 20$ [La Educación popular en los siglos XIX y XX], 2001. 
provinciales, pioneros en el tiempo, y a veces más duraderas que las de su homónimo madrileño, a pesar de su menor entidad e importancia. Tal fue el caso de las publicaciones patrocinadas por el Ateneo de Cádiz (1858-1860), el de Palencia (1877-1881 y 1909), el de Valladolid (El Ateneo, Revista mensual de Ciencias y Artes del Ateneo de Valladolid, 1913-1915) y, muy destacadamente el de Vitoria (El Ateneo, 1870-1874, 1875-1878, 1879-1884 y 1913-1915, y Revista de las Provincias Euskaras, 1878-1879). En el de Madrid, sólo a partir de 1877 cristalizó muy pasajeramente la publicación de un órgano societario, el Boletín del Ateneo. Tampoco tuvo mucho más éxito la tentativa de 1888 y únicamente a partir de 1906 la nueva experiencia - la revista El Ateneo- logró consolidarse durante seis años gracias al esfuerzo del entonces secretario ateneísta, Mariano José del Vals5.

Francisca Soria Andreu menciona al respecto algunas apreciaciones que resultan pertinentes al caso:

«Las instituciones culturales locales del siglo XIX eran el centro de la vida ciudadana: información, lectura, cultura política, celebraciones culturales y lúdicas, exposiciones, representaciones teatrales, conciertos. En el centralista Estado del siglo, estas asociaciones culturales permitían además afirmar la personalidad regional y las señas de identidad cultural diferenciadas, por lo que el debate nacionalista-regionalista se hizo presente en buena parte de ellas ${ }^{56 \%}$.

Aparte de constatarlo así, en efecto, las monografías ateneístas existentes, esta centralidad cultural hizo que con frecuencia se convirtiesen en ejes de la opinión local, cristalizada, si no en todos los casos en órganos societarios propios, desde luego en una activa presencia en la cada vez más asentada prensa local ${ }^{57}$.

Y no sería mucho ver en ello sólo una modulación particular del papel de los ateneos provinciales en la adopción y defensa de la identidad local. Siendo general este hecho, en algunos casos además su papel llegó a adquirir una singular relevancia, en paralelo con otras instituciones e iniciativas culturales y con el movimiento político coetáneo.

El mejor ejemplo a este respecto es, sin duda, el Ateneo Barcelonés. Fundado en 1860 con el nombre de Ateneo Catalán, como ya se dijo, en 1872 se instala en los locales del Centro Mercantil Barcelonés refundiéndose con él y adoptando su actual nombre. Su particularidad catalana apenas se manifiesta en estas primeras etapas por otros detalles que por su colaboración, como pro-

s5 Índices en Sagardia, A.: Ateneo: (Madrid 1906-1912). Madrid, Instituto Miguel de Cervantes del C.S.I.C., 1960.

56 SORIA ANDREU Francisca, El Ateneo de Zaragoza, op. cit.,

57 Lo mencionan expresamente SÁNCHEZ GARCÍA, J. L. con respecto a El Norte de Castilla para el Ateneo de Valladolid (op. cit., p. IX), ÑACLE GARCía a El Defensor de Albacete para el Ateneo Albacetense (op. cit., p. 74), y NAvAjAS Zubeldia-ANDRÉs CABELlo a La Rioja para el Ateneo Riojano (op. cit., p. 98). 
motor de algunos premios, en las manifestaciones literarias y artísticas iniciales de la Renaixença y por un cierto interés por sacar a la palestra de las discusiones el particularismo jurídico e institucional de Cataluña.

Sin embargo, conforme el renacimiento cultural catalán va adquiriendo unas connotaciones sociales y políticas más amplias, el Ateneo barcelonés se verá involucrado en ellas, de la mano de sus sucesivos presidentes: Duran i Bas, Robert, Sol i Ortega, Coroleu, Yxart, Pella i Forgas, Guimerá, Almirall, Permanyer, Domènech i Montaner, Abadal y Maragall, entre otros; nombres, buena parte de ellos; que se encuentran organizando el Congreso Catalanista de 1880, creando el Centre Català y la Lliga de Catalunya, colaborando en la revista La Renaixença, firmando en 1885 el Memorial de Agravios (Memorial de Greuges), redactando en 1892 las Bases de Manresa y, ya más adelante, plenamente integrados en el movimiento político catalanista.

El momento decisivo se produce en los cursos $1895-1896$ y 1896-1897. En el primero, ocupa la presidencia un veterano artífice del renacimiento cultural catalán, Angel Guimerá, secundado en la secretaría general por el joven poeta catalanista, Maragall. En noviembre de 1895, Guimerá recupera la lengua catalana para las actividades culturales ateneístas en un memorable discurso inaugural. $\mathrm{Al}$ año siguiente, la combinación entre catalanismo cultural y político se repite en las personas de Almirall y Prat de la Riba. En 1901, el Ateneo Barcelonés es una de las cuatro instituciones que lanzan a sus respectivos presidentes a la palestra política y consiguen situar los primeros diputados catalanistas en las Cortes españolas, preludio de la emancipación de Cataluña de las coordenadas políticas restauracionistas. En 1903, el poeta Joan Maragall lee en la inauguración del curso su «Elogio de la Palabra». Por estas fechas; el Ateneo es ya plenamente catalanista y ese vínculo ya no se interrumpirá excepto en circunstancias políticas excepcionales. Sin embargo, a partir de estos años, cuando el catalanismo ha comenzado a caminar con pasos propios, el Ateneo Barcelonés parece replegarse más bien sobre intimidad de las ocupaciones culturales y. artísticas. Es la época del dominio de las penyes, prácticamente hasta el comienzo de la guerra civil; refugios de la sociabilidad intelectual con innegable influencia, no obstante, sobre la vida cultural barcelonesa.

Y no se trata sólo del Ateneo Barcelonés. Aunque sin su alcance por obvias razones, casi todos los ateneos conocidos se sumaron con mayor o menos intensidad a esta modalidad particular de lucha por la cultura, bien bajo la fórmula regionalista-nacionalista, bien patrocinando la celebración de Juegos Florales, como los de Zaragoza, Vitoria, Cádiz, Albacete o Sevilla; bien poniendo sobre el tapete las posibilidades culturales y políticas del regionalismo, en el que entraron, en cuanto centros de debate de los asuntos nacionales más candentes, buena parte de ellos; bien en el descubrimiento del patrimonio arqueológico y artístico local e incluso patrocinando publicaciones con este objetivo, como fue el caso de la Revista de las Provincias Euskaras del Ateneo vitoriano. 


\section{Del ATENeo ilustrado al ATENeO De los INTEleCtUAles}

Sin duda, este es el gran cambio que es posible percibir en los ateneos —en el Ateneo de Madrid especialmente en cuanto que agota la secuencia temporal completa del análisis integrado que hemos emprendido- desde la institución ilustrada de sus primeras etapas a otra con un papel privilegiado en la mediación entre cultura y sociedad, de la mano ya en estos momentos de la categoría socioprofesional de los hombres de cultura, llamémosles intelectuales. Lo cual significa prioritariamente que su obra debe ser abordada con los criterios que a tales funciones aplica la ciencia social, es decir, como ámbito de vertebración de un campo de análisis sociológico del hombre de cultura y de sus producciones culturales.

Más que el ateneísmo, lo que a este respecto interesa son los ateneístas y la forma en que a través de estas instituciones se desenvuelven sus estrategias complejas de afiliación, reconocimiento y consagración en el mercado cultural. Queremos hacer referencia en particular a las concepciones sociológicas de los intelectuales y de sus productos culturales del sociólogo francés Pierre Bourdieu, con su concepto de campo en cuanto espacio normativo autónomo donde se despliega el juego de los factores de la estructura social, de los mecanismos materiales de la producción cultural y de los poderes simbólicos ${ }^{58}$.

Fue de nuevo. Manuel Azaña quien con mayor perspicacia dio forma a un análisis social del ateneísmo - es cierto que una perspectiva fundamentalmente política, fácilmente comprensible en la coyuntura de 1930 - al encarnar en el carácter público de sus políticos e intelectuales las grandes mutaciones históricas de la nación ${ }^{59}$. Pero, al hacerlo así, trazó también al fin y al cabo los caracteres de una dialéctica general del campo cultural desde el que los nuevos políticos liberales habían «racionalizado» la legitimidad de su asalto al poder y que se había reconstituido a lo largo del siglo en su plena autonomía como campo de disputa de los recursos económicos y simbólicos del también nuevo hombre de cultura «institucionalizado» en los sistemas culturales estatales y en los mecanismos de producción cultural privada. El «tiempo nuevo», vino a decir, tropieza siempre con un obstáculo insalvable: «la posesión del mundo por otras gentes, que no admiten ser desahuciados de su posesión»; gentes que también, en otro tiempo, quisieron "acomodar el mundo a su imagen»: expulsaron y reemplazaron a otros, "como ahora se ven en trance de expulsión y reemplazo» ${ }^{60}$. Ahí, en esa dialéctica del cambio histórico y cultural, los ateneos eran organismos de límites borrosos, «durable(s) a causa de su libertad», modelables sobre lo ur-

\footnotetext{
58 Ver como ejemplo concreto de estos análisis BouRdieU, Pierre: Las reglas del arte. Génesis y estructura del campo literario. Barcelona, Anagrama, 2002. Sobre el conjunto de su obra, ver PINTO, L.: Pierre Bourdieu et la théorie du monde social, Paris, Albin Michel, 1998.

59. Nos referimos obviamente al importante discurso de apertura de las cátedras del curso 1930-1931, leído el 20 de noviembre de 1930: «Tres generaciones del Ateneo», en AZAÑA, Manuel: Obras Completas, vol. I, México, Oasis, 1966, pp. 620-637.

60 Ibid., p: 636.
} 
gente y sobre las necesidades y contenidos menos disímiles a cada ser personal - palabras aplicadas al de Madrid, aunque, sin duda, válidas para el conjunto del ateneísmo - ${ }^{61}$, un campo para las legítimas ambiciones de cada uno y para la muy liberal ilustración de todos.

Las tres generaciones que se habían sucedido en el Ateneo de Madrid hasta 1930 portaban a su parecer el estandarte de la conciencia pública del liberalismo español: hombres, primero, de interesada componenda entre el viejo y el nuevo régimen, de falseada conciliación liberal después, de ruptura finalmente, desde comienzos del siglo XX, con el Estado, no obviamente en su estricto significado de «categoría jurídicá, sino como representación, guía y tutor de una continuidad histórica» ${ }^{62}$. En la primera etapa, los ateneos son políticos en la medida en que la vida pública y todos aquellos medios e instituciones alineados en torno a esa línea de fuerza constituyen el eje vertebrador de la autodeterminación individual en las primeras etapas del liberalismo. Sus mecanismos de recompensa resultan ser básicamente aquellos que enmarcan las instituciones políticas y los organismos públicos alineados en esa polaridad, aunque sean compatibles también con otras de índole profesional. Sólo que en esta etapa ambos campos de acción se solapan habitualmente y proporcionan el perfil propio del político-literato o político-erudito-periodista, que tan bien se acomoda al fenotipo del hombre liberal en general. Son todo ellos, conforme a las observaciones de Giner de los Ríos, hombres que pasan de las aulas de derecho a las «sociedades de hablar», de éstas a las Cámaras y de allí al Gobierno ${ }^{63}$, y que en las prácticas de domesticación y de civilidad de estos espacios se van perfilando las credenciales de su pertenencia al poder liberal, incluidos sus riesgos más frecuentes, como el procesamiento, la persecución, el exilio y hasta la propia vida.

El Ateneo de Madrid fue el primero en el tiempo, y el más reputado después, de estos escenarios de la dialéctica de la palabra y del poder, un centro que infundía credibilidad y promovía el razonamiento público, que imponía su magisterio en las prácticas oratorias, tan esenciales en la dialéctica del liberalismo decimonónico, y que en esas tareas iba creando un poso de prestigio, que acompaña siempre imperativamente al poder político y económico efectivo de las élites sociales: «la posibilidad de hablar libremente - de nuevo Azañalabró la reputación del Ateneo, convertido en lazareto del librepensamiento" ${ }^{64}$. «Las discusiones fueron antaño su principal razón de ser», confirmaba Unamuno ${ }^{65}$. Y según Palacio Valdés, quien publicó coetáneamente en la Revista Europea las semblanzas de los más reputados oradores del Ateneo (el P. Sánchez, Moret; Perier, Valera, Moreno Nieto, M. de la Revilla, Gabriel Rodríguez, F.

61 Ibid., p. 631.

62 Ibid., p. 632.

63 GINER DE LOS RíOS, Francisco: «Sobre el estado de los estudios jurídicos en nuestras Universidades», en Obras Completas, t. II, La Universidad española, Madrid, 1916, p. 174.

64 AZAÑA, Manuel: Memoria leída leída en el Ateneo de Madrid, op. cit., p. 431.

65 UNAMUNO, Miguel de: «La evolución del Ateneo de Madrid», op. cit., p. 367. 
de P. Canalejas, F. J. Galvete y Castelar), recopilándolas en 1870 como libro ${ }^{66}$, «todas sus discusiones previamente anunciadas sobre un tema concreto vienen precipitadamente a parar en puro asunto teológico o político» ${ }^{67}$.

Ya no será tan habitual este perfil, sin embargo, a partir de la época de la Restauración. Los centros de polaridad intelectual comenzarán a diversificarse considerablemente y las carreras política, cultural, artística, profesional se integrarán en campos relativamente autónomos, con sus particulares hábitos de funcionamiento y sus mecanismos de promoción institucionalizada, aunque todavía conciban difícilmente un cursus honorum no coronado en su vértice por una cierta consagración política. Pero a juego con las imposturas políticas del propio régimen, las carreras profesionales y las públicas de sus representantes más reputados se enmascaraban, a juicio de Azaña, en un juego de ocultación, de mueca cínica, entre lo que eran y lo que representaban:

«Cánovas, en el ápice del poder, quisiera ser gran prosista, crítico e historiador. Valera, no contento con su autoridad de escritor, ambicionaba ser ministro... Castelar quisiera ser novelista sin observación, e historiador sin método. Campoamor, más filósofo, tomaba el sol en el Retiro, viviendo sus Doloras, y oía misa los domingos por no oír a su mujer» 68 .

La nueva generación, la del 98 - dirá por último Azaña- desenmascarará este mundo de ficciones, "rompiendo con el acatamiento a lo consagrado" y abriendo una enconada pugna «de la gente nueva contra los viejos». Sin necesidad siquiera de gobernar la institución, le infundieron, desde sus distintas «aplicaciones del talento y del trabajo", una nueva sensibilidad para elevar la inteligencia hacia los problemas generales de interés nacional. Ese fue el «efecto capital» de su obra, sobre la institución y sobre la conciencia pública nacional del siglo:

«Buen síntoma fue que empezara a extinguirse la correspondencia tradicional entre la órbita ateneísta y el mundo político, singularmente el parlamentario» ${ }^{69}$.

Ahí, espoleados por ese crucial cambio, los ateneos mantendrán su presencia, su capacidad de resonancia en virtud de las credenciales públicas que les son atribuidas a su condición de «Doctas Casas». Eran con toda propiedad el centro vital de las élites culturales de carácter nacional o local: políticos, abogados militares, médicos, farmacéuticos, profesores de Universidad o de Instituto, poetas, pintores, eruditos, periodistas, etc. Representaban con cierta frecuencia la gran divisoria entre el éxito y el anonimato en todas esas ocupaciones, los que domi-

\footnotetext{
66 PALACio Valdés, Armando, «Semblanzas literarias: Los oradores del Ateneo», en Obras Completas, t. II. Madrid, Aguilar, 1970, pp. 1157-1188.

67 Ibid., pp. 1159-1160. Numerosos datos sobre ateneístas ilustres también en ARAúJO CosTA, Luis: Biografía del Ateneo de Madrid. op. cit., Madrid, 1949.

68 AZAÑA, Manuel: «Tres generaciones del Ateneo», op. cit., pp. 628-629.

69 Ibid., pp. 630-632.
} 
naban los rituales de integración del neófito en el olimpo de la cultura pública reconocida, los que administraban su crédito público: un centro - confiaba Unamuno sobre el de Madrid - «al cual debo mucha parte de mi nombre en España $»^{70}$. Azaña mencionaba en su primera memoria como secretario $1^{\circ}$ del Ateneo de Madrid el caso - real o inventado, es lo de menos- de un hombre vencido por la vida que un día, a la salida de la Casa, le abordó con la pretensión de dar una conferencia en su cátedra. Tenía, observaba Azaña, «más hambre que letras», pero «mendigaba dos cosas que en un país libre no pueden negarse a un ciudadano: un pedazo de pan y una tribuna donde pronunciar un discurso", un lugar donde triunfar y "confundir a sus enemigos» ${ }^{71}$.

Otro caso de índole semejante narraba Cansinos Asséns: el de una ascendente estrella de la cátedra de café, Alfonso Segundo Uriarte de Pujana, perito, al parecer, en los arcanos del ascetismo oriental, que le permitían vivir sin comer, a quien se confió por un día la del Ateneo a fin de que pudiese irradiar su luz a los ámbitos cultos madrileños y que, una vez en ella, incapaz de articular palabra, concluyó por terminar estrellado, también en su doméstica gloria bohemia. "Ahora tienes la ocasión de lucirte... En una noche te puedes hacer un nombre... El Ateneo es un trampolín», le decían sus compinches. Para colmo, se comprobó que no eran sus conocimientos orientales lo que le permitía vivir sin ocupación, sino la protección de «la Cristina, una vieja cocotte que se pasea[ba] por la Carrera de San Jerónimo guiñándole el ojo a los viejos verdes» 72 .

Un último testimonio servirá para ilustrar esta dimensión vicaria del ateneísmo que venimos señalando, un testimonio en primera persona, aunque sintomático de la forma en que el joven creador se abría paso a codazos en la vida intelectual europea de los años veinte. Lo narra en sus memorias César GonzálezRuano, todavía muy joven y con un desordenado apetito de hacerse un hueco en la corte literaria, de «romper el hielo», según decía. ¿Dónde hacerlo? Ni que decir tiene, ien el Ateneo! Era a comienzos de enero de 1922, se celebraba un homenaje a Cervantes y allí fue él, aupado entre la nómina de conferenciantes, como «el anarquista que lleva su bomba». «Ese Cervantes — vino a decir- parece que era un manco, cosa que se confirma, porque El Quijote está escrito con los pies» y así siguió hasta conseguir salir del Ateneo escoltado por la policía y que al día siguiente los periódicos hablasen de él, aunque fue mal: «eso quería yo»: Sólo se sintió herido por $\mathrm{La} V o z$, que tituló su crónica: «Al Señor González no le gusta Cervantes», así, sin Ruano, lo que era tanto como dejarle en el anonimato. De hecho, el año 1922 fue el de su despegue en la notoriedad literaria, lo que prueba que «el escándalo del Ateneo [le] hizo algún bien»"73.

70 UNAMUNO, Miguel de: «La evolución del Ateneo», op. cit., p. 370.

71 AZAÑA, Manuel: Memoria leída en el Ateneo de Madrid, op. cit., p. 433.

72 CANSINOS Asséns, R.: La novela de un literato. (Hombres-Ideas-Efemérides-Anécdoras...), 1 (1882-1914), Madrid, Alianza Tres, 1996, pp. 225-227.

73 González-Ruano, C.: Mi medio siglo se confiesa a medias. I, Antes del mediodia (Memorias), Madrid, Fundación Cultural Mapfre Vida, 1997, pp. 131-135. 
Parábolas todas de los laberintos - con cierta frecuencia cegados- del reconocimiento intelectual remiten por igual al poder simbólico que el Ateneo de Madrid - y con él el resto de los ateneos - podía impartir con creces: hospitalidad, crédito intelectual, resonancia, reconocimiento:

«Excita la curiosidad personal mediante su biblioteca y debates, pero recibe y amplía impulsos individuales, es móvil, es resonador; recoge y propone. Muy pródigo y complejo, a veces fútil, con malgasto de tiempo y energía, es la más durable creación libre de un siglo, durable a causa de su libertad, que nos permite modelarlo sobre lo urgente. Borroso de límites, podemos pensarlo a nuestro modo, darle el contenido menos disímil con nuestro ser personal» 74 .

Este es el diagnóstico definitivo de su socio más ilustre del siglo XX: Manuel Azaña. Nada lo ilustra mejor que la periódica reseña de sus actividades en los órganos de prensa, convertida en un hábito periodístico local, repetido mecánicamente como quien recoge la temperatura política y cultural del medio y que, con cierta frecuencia, ha permitido a posteriori la tarea de documentación histórica de las actividades ateneístas, a falta de otras fuentes archivísticas más directas, a veces previsoramente dispersas en la confusión de la guerra civil a fin de que sus testimonios documentales no se convirtiesen en pruebas de acusación y, en otras, consecuencia de un malhadado desprecio hacia la memoria histórica de la tradición liberal española (esto es cierto para el Ateneo de Madrid, cuyos archivos fueron incautados después de la guerra y desaparecieron en un incendio y lo señala también Sánchez García para el de Valladolid).

Así se puede explicar la gran ruptura histórica de la época franquista, que expuso a los ateneos a una doble fatalidad. Por una parte, la tutela absorbente del poder público contradecía de raíz el impulso fundacional de la cultura libre, siquiera tendencial, en que habían nacido, y, por otra, quebraba un estado de presencia activa en la vida cultural y política nacional y local. Por estas razones, más que por su inevitable adaptación a la concurrencia con el conjunto de nuevas instituciones y ámbitos culturales, la vida histórica de los ateneos quedaba truncada a partir de entonces, tal vez de forma definitiva, aunque en algunos casos su estricta existencia administrativa haya pervivido hasta nuestros días.

74 AZAÑA, Manuel: «Tres generaciones del Ateneo», op. cit., p. 631. 